\title{
上顎骨の前方拡大の実験的研究
}

一 骨切り術を応用して -

九州歯科大学矯正学教室 (指導: 横田成三教授)

九州歯科大学病理学教室 (指導 : 浦郷篤史助教授)

$$
\text { 大学院横田盛 }
$$

（昭和46年 9 月20日受理）

\section{EXPERIMENTAL STUDIES ON ANTERIOR EXPANSION OF MAXILLA - BY APPLYING OSTEOTOMY -}

\author{
$\mathrm{By}$ \\ Shigeru YOKOTA \\ Department of Orthodontics (Director: Prof. Seizo YOKOTA) \\ Department of Pathology (Director: Assoc. Prof. Atsushi URAGO) \\ Kyushu Dental College, Kitakyushu, Japan
}

The correction of severe cases of mandibular protrusion such as are encountered in an underdeveloped maxilla is difficult to achieve by conventional orthodontic approach alone. In the present study, an attempt was made to develope a new method of treating such cases by means of operative orthodontics.

A total of 26 adult dogs weighing about $20 \mathrm{~kg}$ were served as experimental animal and artificial fracture was made on both sides of the maxilla in the space between the 3rd incisor and cuspid.

The fractured space was mechanically widened respectiveiy in one of the following manners.

1) Separate the space by surgeon's hand as wide as possible and keep it in position by applying an acrylic resin splint. This was designated as spaced fixation method.

2) Expand very slowly $(0.2 \mathrm{~mm}$ per day) over an extended time duration (40 days) the fractured ends by use of a screw expansion plate. Slow expansion method.

3) Expand the fractured ends in the shorter period (in 20 days and by $0.7 \mathrm{~mm}$ per day). Rapid expansion method.

On 40,70 and 100days after completion of respective experiment, observation were made on the state of newly formed bones in the extended space and of teeth and surrounding tissue in the anterior maxillary segment, by mesurement of plaster cast and by macroscopic, roentogenographic and pathohistological examinations of the maxilla.

Results of the study were summarized as follows.

1) Measurement by the plaster casts showed that the maximum and mean values of space attained by rapid expansion method was respectively $12 \mathrm{~mm}$ and $10 \mathrm{~mm}$, by slow expansion method $8.0 \mathrm{~mm}$ and $7.5 \mathrm{~mm}$, and by spaced fixation method $4.5 \mathrm{~mm}$ and 3.6 $\mathrm{mm}$ respectively. 
2) The newly formed bones at the fractured space were mainly consisted of uniting callus, and osseous healing was complete about 100 days after fixation of maxilla by rapid expansion method and spaced fixation method. By slow expansion method, however, a marked retardation of osseous healing was shown probably due to an unfavorable effect of constant stimuli given to the blast tissue for too extended time duration.

3) As a general effect of the experimental fracture of maxilla, the tooth pulp was replaced by granulation tissue, and especially in case of slow expansion method, a severe resorption of tooth root due to the inflammatory granulation of alveolar basis was observed. In cases where rapid expansion method and spaced fixation method were applied, however, the tooth root suffered only slight degree of resorption of the dentin and cement substances.

4) Because $X$-ray observations of the operated maxilla were quite in parallel with those obtained by pathohistological means, $\mathrm{X}$-ray finding may be most advantageous in following the course of bone formation and in judging when is the time of osseous healing.

In view of the above, it was concluded that rapid expansion method proved most advantageous in achieving the anterior expansion of maxilla by operative orthodontics.

\section{I 緒言}

矯正治療の目的は，歯。歯周組織，顎骨およびこれら 亿付随する諸組織の正常な発育, 成長を研究すると同時 に，てれらの異常によって生じた咬合の不正，顎骨の形 態異常和よび顔貌の不良による心理的障害をあ取り除く こと1)を目的にしている。

さて，各種の不正咬合のうち，いわゆる反対咬合は日 本人に特徽的に多く，アメリカでは矯正患者の $2 \sim 3 \%$ が下顎前突である2のに比し，日本人では患者の30\%以 上を占めている3).

このいわゆる反対咬合む，単に上下前歯の前後的位置 関係に起因する場合と，歯牙抢よび歯牙支持組織の基底 をなす上顎骨体部の前後的関係任異常が存在する場合之 があり、ての両者は治療にあたっては異なった治療方 針，方法の選択が行われ，また，予後の判定にも根本的 な差異をきたすすのである。このため顎態の分析につい ては多くの先人の報告がなされ，Wallace4）はいわゆる 反対咬合には上效の成長抑制があることを予測し， HeI mann5)はこれを外貌より形態学的に証明した。 また。 Moore6) は遗伝学的立場より上顎骨基底の劣成長を指摘 している。

1931年, Brodbent7)によって導入された頭部 X線規格 写真法は, 顎顔面頭蓋の形態の把握を可能にした．わが 国であ粥川8）はレントゲンセファロによる日本人反対咬 合の形態学的研究により，上须骨部之蒾槽部の後退があ ることを実証し，単に反対咬合が局所に限局されたもの
ではなく，顔の形態や成長に 関係があるととを示唆し て, 顔の上方中央部 の前後的な成長が劣ると述べてい る. 次いで山口 ${ }^{9)}$ はこれを量的にとらえて, 下顎骨が近 心に転位している症例（10１5\%）よりはむしろ上顔面 部および上顎前歯の後退している症例（50～70\%）が多 い之報告している，またその後，須佐美10) あ反対咬合者 の上䫟基底部は成長にともなう変動がきわめて僅少であ ることを指摘している。

さててのように本邦に执いて比較的頻度の高いいわゆ る反対咬合の治療に際しては，上顎前歯の唇側移動が行 なわれてきた。乙の場合，歯牙を含む上顎前歯の歯槽骨 が変化するてとは臨床的に明らかであるが，顎基底まで あ変化させ得る可能性はほとんどない，したがって上簤 骨の劣成長をとむなういわゆる反対咬合に拀いては，根 本的な治療の効果を得られる期待は少なく，外観上るそ の特徴的な“中くぼみ”型を改善することはできないので ある。すなわち “顎の基底部に相当する部分は，矯正治

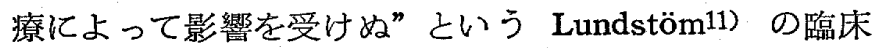
に基ずく考えは現在まで広く矯正学の常識として受け入 れられてきた。

しかし最近になって，顎骨と正中口蓋縫合部に执いて 側方一拡大させる方法が注目されるようになり，臨床的 12 22)にあ，また，基礎的23 299にあ多くの報告がなされ て㧍り，Haas ${ }^{24)}$ は上顎骨の側方桩大の際，前下方への 拡大をもとむなうと述べている。

以上のように従来の上顎骨の拨大は，正中口蓋縫合を 
非観血的に侧方へ離開させ，付随的には前下方への拡大 がわずかに可能であることを示してはいるすのの, 下顎 前突症にむっとも問題となる上顎骨の前後的劣成長を積 極的に解決できる手だてとはなり得ない．

そこで著者は，上顎骨の劣成長による上下顎骨間の位 置関係の異常を正常に改善するには，上顎骨に観血的手 段を併用して, 同部を前後的に拡大する方法が有効であ ると考元，新しい治療法を開発するため本実験を行なっ た.

\section{（1）実験材料}

\section{II 実 験 方 法}

上類骨における実験的前方拡大に，個体の成長要素が 加わるのを避故るため, 動物は成熟した雑犬26 頭を選 び，その選定にあたっては動物の大きさのバラッキが少 なくなるよう，また手術侵襲に耐え，かつ実験 操作が 容易という点から体重 $20 \mathrm{~kg}$ 前後の比較的大型のものを 使用した。

\section{(2) 手術方法}

ペントバルビタールナトリウム（市販名：ソムノペン チル）を $0.4 \mathrm{ml} / \mathrm{kg}$ 静脈注射し，全身麻酔のもとに手術 した。

左右それぞれの $\mathrm{I}_{3}$ とC の間に骨膜に達する縦切開を 加えた。

左右の切開部より，上頢骨頓側面の骨切り予定線に沿 ってそれぞれ鼻腔側に至るまでラスパトリウムを挿入 し，骨膜を骨皮質より剥離し，同様に口蓋側でも左右縦 切開部より鼻口蓋神経, 血管を損 傷せぬよう十分注意 し，ながら剥離を行なった．さらに粘膜骨膜の剥離は骨 切り予定線が全周にわたって袋状に包まれるよう幅広く 行なった。これはその後に行なう䫈骨の前後的拡大に際 して，骨膜が抵抗源となり，また桩大力により骨膜線維 が断裂するのを防止するためである。

骨切りは煩側に抬いては， I $I_{3}$ と C の中間部で C の 歯根近心面に沿って菲薄なノミを使用して離断し, 左右 側の骨切り線は鼻背側で合致させ，口蓋側も同様に鼻口 蓋神経，血管を損傷しないようにしながら離断した。か くして左側 $\mathrm{I}_{3}$ より右側 $\mathrm{I}_{3}$ を含む小骨片は, 左右 $\mathrm{C}$ を 含む大骨片より完全に骨切りされたことを確認した後, 切開部を縫合し手術を終えた．次いで術直後 Penicillin G-sol を60万単位, 翌日からは30万単位を連続 5 日間筋 注した.

（3）拡大装置之拡大方法

骨折端を離開させるため，大，小骨片に菌牙を含めて
拡大床を装着させ，（図 1，2），拡大法によって次の 3方法に分類した。

A) 漸次的に器械力に上り拡大する方法

1）急速拡大法 (rapid expansion)：7例

大骨片の左右犬歯を固定源とし，あらかじめ作製して おいたレジン床を即時重合レジンで固定させた。 小骨片 あ同様に右側 $I_{3}$ 左側 $I_{3}$ に至る前歯群にレジン床を固 定させ，前後のレジン床の間には骨折部を離開させるた めのネジである矯正用 expansion screw，を即時重合レ ジンで取りつけた．拡大量は $0.7 \mathrm{~mm} /$ 日で20日間の動的 期限終了後, 搪大床を固定床に取り換え，40日，70日， 100日の固定期間に分類した.

2) 緩徐拡大法 (slow expansion) : 5 例

1）之同じ拡大装置で， $0.2 \mathrm{~mm} /$ 日の拡大を 40 日間継 続したもので，比較的長期にわたって徐々に䫈骨の前後 的拡大を行ない，40日，70日，100日の固定期間を置い た.

B）一時的に器械を使用せず拡大を行なう方法

離開固定法 (spaced fixation) $: 6$ 例

骨切り直後, 同部を可及的幅広く離開させ，しかも平 行になるよう，離開した状態で固定床を装着して䫇骨の 前後的拡大を行ない，40日，70日，100日の固定期間を 置いた。

\section{（4）検索方法}

I) 模型分析

骨折端の搪大量を測定し，また固定歯である上顎犬歯 の動きをああわせて知るため，アルヂネート印象を術 前, 術後に採得し，石言模型を作製した。模型上で術前 にあらかじめ附与しておいた $\mathrm{I}_{3}, \mathrm{C}, \mathrm{M}_{1}$ の歯頸部の切 れ込みを計測点として、 $\mathrm{I}_{3} \sim \mathrm{C}$ を顎骨拡大量, $\mathrm{C} \sim \mathrm{M}_{1}$ でCの移動量を, 術前と術後の模型から矯正用キャリパ 一で計測した.

\section{2) X 線学的観察}

骨折端の離開形態，骨新生状態を知るため，骨切り 前, 後および固定後にX線撮影した. 撮影条件は歯科用 $\mathrm{X}$ 線撮影装置を用い，骨折端拡大前後のフィルムの重稀 合わせができるように，主放線が実験犬の上頢犬歯の近 心を通過するようにし，焦点一フィルム間距離を $50 \mathrm{~cm}$ に統一した。

\section{3) 病理組織学的検索}

固定期間終了後, 屠殺し, 線鋸で上顎骨を切断した. さらに矢状方向に 3 等分した後，10\% ホルマリン固定 し, 電気脱灰 ( $79 \%$ 塩酸) を施てし, 通法にしたがって セロイジン包埋, $20 \mu$ 連続切片とし，H-E 重染色，アザ 
ン・マロリー、エラスチカ・ワンギーソン染色を行なっ て検索した。

\section{III 実 験 成 續}

本実験遂行中，実験動物に抏こった不虑の事故（術後 合併症 3 例, 事故死 2 例, 拨大中あるいは固定中に床装 置の把持が不十分で，骨片の維持が不完全であったもの 了例にてあったものは資料から除き, 全資料の完備した 26頭中18例について観察を行なった。

1) 肉眼的観察

急速桩大法：骨切り後, 20日間の急速桩大による動的 期間終了後，40日，70日，100日 上固定を行ない，保定 床を除去した。拡大床下の粘膜は，床との間に停滞した 食渣やレジン床による刺激のためか，発赤する傾向がみ られ，接触すると粘膜から出血するすのああった。

口腔内に打汀る術前, 術後の上下顎関係を比較する 之, 全症例之屯上顎切柬部の前方拡大がみられ，術前に 反対咬合であった症例（写真I）でも，術後には著し い拡大によって逆に上顎前突をきたす程であった（写真 2). 外観側貌では，顎基底部の拡大に.よるため鼻尖が 突出し, 顔面中央部は単なる歯牙の唇側移動では得られ ないいわゆる“中高か”の顔面形態を得ることができ た.

拡大ネジによって前方移動した小骨片は，手指による 外力によっても可動性は全く認められず，離開部の両骨 端は完全に骨性癒合をしているように思われた。同部の 骨の新生状態を直視するため, 粘膜骨膜を剥離して骨表 面を露出させたところ，固定40日目のものでは表面の一 部にわずかの線維性結合織の残存しているものがみられ たが，固定期間が70日目，100日目之経過するにつれ， 離開部を補填する新生骨は在来骨との識別が困難な程に なった。

緩徐拡大法 : 急速拡大法に比して，小骨片の前方拡大 量は少ない。しかし上顎霜列から判断すると，拡大され た小骨片内の切歯は，術前上り傾斜する傾向がみら机 る.すなわち骨片全体が前上方へ回転している。しかし 拡大量が小さいため, 外観に影響を㧍よぼすほどの変化 はもたらさなかった。

固定床下の粘膜は一般にかなり強い炎症々状を示して いる. 固定40日目では骨表面には多量の線維性結合織を 含む仮骨形成を思わせたが，固定期間が長期になるにつ れ，口蓋粘膜は㷊爛状となり，固定70日目では口蓋粘膜 に穿孔をきたし，鼻腔と交通し，固定100日をを待たず実 験完遂前に鼻孔よりの排膿を之もない死の転帰をたどっ
た.

離開固定法：骨切り直後，同部を最大に拡大した状態 で固定したにもかかわらず，器械的拡大を行なった他の 2 万法にはその拡大量は抽よばず，最小であった。また 小骨片の拡大状態は，可及的平行移動して固定したにも かかわらず前上方へ転位する傾向を示した，骨膜を剥離 し直視下での仮骨形成を観察すると，固定40日目で表面 にわずかの残存結合織をみたが，小骨片の可動性は全く みられず，固定70日では骨表面に結合織はほとんど認め られず，旺盛な骨修復が行なわれ，固定 100 日目では完 全なる骨癒合を認めた。

2) 模型計测

拡大床によって得られた拡大距離を実測するため，骨 切り端にもっとあ近い $\mathrm{I}_{3}$ と C の距離の術前, 術後の差 で拡大距離を表わし，表1に示した，急速拡大法は最大 $12 \mathrm{~mm}$, 最少 $9.0 \mathrm{~mm}$, 平均 $10 \mathrm{~mm}$ と 3 方法中最大の搪大量 であるが，拡大ネジによる予定拡大量 $14 \mathrm{~mm}(0.7 \mathrm{~mm} \times$ 20）之は必らずしも一致していない．同様に緩徐拡大法 でも最大 $8.0 \mathrm{~mm}$, 最小6. $0 \mathrm{~mm}$, 平均 $7.5 \mathrm{~mm}$ 上予定量を 下まわっている.離開固定法では他方法之同様に，骨切り 前に幅広い骨膜剥離を行ない，最大に離開させたままで 即時に固定したにもかかからず，最大 $4.5 \mathrm{~mm}$ 最小 2.0 $\mathrm{mm}$, 平均3. $6 \mathrm{~mm}$ といずれも 3 方法中最小の值しか示さ ない，上顎骨の前方应大にともなう固定源の左右犬霜は， 反作用之して遠心移動がみられ，急速桩大は最大法 1.5 $\mathrm{mm}$, 最小 $0 \mathrm{~mm}$, 平均 $1.0 \mathrm{~mm}$, 緩徐拡大群最大法 $2.5 \mathrm{~mm}$, 最小 $0 \mathrm{~mm}$, 平均 $1.2 \mathrm{~mm}$, そして 離 開固定法最大 0.9 $\mathrm{mm}$, 最小 $0 \mathrm{~mm}$, 平均 $0.4 \mathrm{~mm}$ であり, 離開固定法は最 あ小さな反作用しか受けていなかった。

3) X線学的成績

X 線所見を記述するにあたり，仮骨の名称は Weinmann ${ }^{43)}$ の分類にしたがった。すすな方ち骨皮質に接して 形成される Anchoring callus, 骨䯣内に形成して骾羫 を閉塞する Sealing callus, 両骨端に形成された Anch oring callus を連結する Bridging callus および両骨 端の骨皮質を結合する Uniting callus に分け観察し た。

(1) 急速拡大法：

固定40日所見：骨折端拡大部の顂側中央より鼻腔側に かけていまだ淡い雲状陰承がみられ， sealing callus の 形成はみられない。しかい口蓋側执よび鼻背側では明瞭 なる不透過像を呈し， uniting callus の形成は玍盛であ る.しかし, uniting callus の周辺には anchoring callus はほとんでみられず，口蓋側では骨離開部へ向 


\begin{tabular}{|c|c|c|c|c|c|}
\hline 拡大法 頃 目 & 動物番号 & 動的期間 & 固定期間 & 拡大距離 & $\mathrm{C}$ 遠心移動 \\
\hline $\begin{array}{l}\text { 急 } \\
\text { 势 } \\
\text { 法 }\end{array}$ & $\begin{array}{l}15 \text { 号 } \\
27 \prime \prime \\
10 \prime \\
12 " \\
29 \prime \\
13 \prime \prime \\
26 "\end{array}$ & $\begin{array}{c}20 \text { 日 } \\
\text { " } \\
\text { " } \\
\text { " } \\
\text { " } \\
\text { " } \\
\text { " }\end{array}$ & $\begin{array}{c}40 \text { 日 } \\
" \prime \\
70 \text { 日 } \\
" \\
" 1 \\
100 \text { 日 } \\
" \prime\end{array}$ & $\begin{array}{l}11.0 \mathrm{~mm} \\
10.0 " \\
12.0 " \\
10.0 " \\
9.5 " \\
9.5 " \\
9.0 "\end{array}$ & $\begin{array}{l}\text { Omm } \\
0.9 " \\
1.5 " 1 \\
1.5 " \\
1.1 " \\
1.0 " \\
1.0 "\end{array}$ \\
\hline $\begin{array}{l}\text { 繹 } \\
\text { 垫 } \\
\text { 法 }\end{array}$ & $\begin{array}{l}25 \text { 号 } \\
14 \prime \prime \\
23 \prime \prime \\
28 \prime \prime \\
16 \prime \prime\end{array}$ & $\begin{array}{c}40 \text { 日 } \\
\text { " } \\
" 1 \\
" 1\end{array}$ & $\begin{array}{c}40 \text { 日 } \\
\prime \prime \\
1 " \\
70 日 \\
\prime \prime\end{array}$ & $\begin{array}{l}8.0 \mathrm{~mm} \\
7.5 \prime \\
8.0 \prime \\
6.0 " \\
6.5 \prime\end{array}$ & $\begin{array}{l}2.0 \mathrm{~mm} \\
2.5 " \\
0.4 " \\
0 \\
1.0 "\end{array}$ \\
\hline $\begin{array}{l}\text { 離 } \\
\text { 笄 } \\
\text { 宽 } \\
\text { 法 }\end{array}$ & $\begin{array}{l}24 \text { 号 } \\
18 ” \\
31 " \\
21 " \\
11 " \\
6 \prime\end{array}$ & $\begin{array}{l}\text { O日 } \\
\text { " } \\
\text { " } \\
\text { " } \\
\text { " }\end{array}$ & $\begin{array}{c}40 \text { 日 } \\
\text { " } \\
70 \text { 日 } \\
100 \text { 日 } \\
\text { " } \\
\text { " }\end{array}$ & $\begin{array}{l}4.0 \mathrm{~mm} \\
2.0 " \\
4.0 " \\
3.5 " \\
4.5 " \\
3.5 "\end{array}$ & $\begin{array}{l}0 \mathrm{~mm} \\
0.9 \prime \\
0.5 " \\
0.5 " \\
0.7 " \\
0 "\end{array}$ \\
\hline
\end{tabular}

って陷凹した像を示す（写真 3）.

固定70日所見：骨端桩大部頓側中央に残された透過像 あやがて uniting callus により陰影が著明となり，ロ 蓋側1/2ではすでに仮骨像の硬化がみられる（写真 4).

固定100日所見：離開部は uniting callus でみたされ ，その仮骨は硬化を示し，骨折線は認められない，骨切 りによる両骨断端は，新生骨により骨性癒合がほぼ完成 されている (写真 5 ).

手術前と拉大後のそれぞれの側方レントゲン写真を重 ね合わせて (図 4) 顎骨の形態変化を観察すると，小骨 片は全体として前方への 著明な 拡大がみられた。回蓋 側の拡大量は鼻腔側の離開量に比して大きく，したがっ て小骨片はやや上方へも軽位していた．顎骨を被う軟組 織, ことに鼻尖，口唇は術前に比し，前方への突出が明 瞭であり，鼻背側すやや上方へ転位する傾向がみられる (园 4 ).

\section{(2) 緩徐拡大法}

固定40日所見：骨端離開部は一般に陰影は薄く，仮骨 の出現は遅れており，口蓋侧で一部 uniting callus に よる連結がみられるが，大部分では骨性架橋は認められ ず， 口蓋側より鼻腔側中央に向う带状の透明層を形成 し, 骨断端辺縁での anchoring callus や bridging calllus あほとんど認められず，仮骨形成の遅れは著るし
い(写真 6).

固定70日所見 : 離開部での透過像は濃度を増すことは なく，むしろ周囲骨を破壊し小骨片の切䨑々槽骨にも波 及し，同部では骨吸収像を呈する，骨辺縁，ことに切宷 の口蓋側では維密骨が失なわれ，骨離開部との交通がみ られる(写真 7). しかし 5 例中, 例外的に1例のみは 極めて旺盛な仮骨増加を示したものがあり，骨端離開部 は良好な骨性架橋をしていた。

手術前, 固定後の側方レントゲン写真の重ね合わせ（ 困 5 ) によると，鼻腔側を中心とする前上方への転位が みられ，骨端離開の形態は楔状を呈している，一方軟組 織の術後における変化をみると，鼻尖，上口唇は前上方 へ突出して㧍り，したがって術前に直線的であった舅 背は術後に凹部を上方へ向けた䛓曲を示すようになって いる(図5).

(3) 離開固定法 :

固定40日所見：口蓋および鼻背部の骨断端辺縁では， anchoring callus の形成はほとんどみられない. しか し, 旺盛な uniting callus の増生により骨折端は架橋 されている，離開部煩側中央ではいまだ紡鍾形状の骨透 過像がみられるが，その中心では樹枝状に伸びた仮骨像 がみられる (写真 8 ).

固定70日所見：離開部中央に残る透過像は，周辺から 
の旺盛な仮骨増加により，細い带状の孤立した除影とし て残されている. 骨折端周辺での anchoring callus 形 成は明瞭でない（写真 9).

固定100日所見：離開部は uniting callus により完全 に充填され，仮骨は硬化し，在来骨との境界も不明瞭で あり，骨癒合のほぼ完成した像を思わせる（写真10）。

術前，術後の側方レントゲン重权合わせによると（図 6)，小骨片は平行搪大を意図したにもかかわらず，口 蓋側の離開のみが維持され，鼻背側の離開は行なわれず , したがって離開形態は緩徐桩大群と同様に楔状を示し た。

買骨を被う軟組織も鼻尖が前上方へ転位した結果，術 前に比し鼻背は彎曲し, 鼻尖, 上口唇の前方突出屯著明 ではない(図6).

4 ) 病理組織学的所見

A) 離開部新生骨について

(1) 急速拡大法

固定40日：煩側中央部, 鼻背側 $1 / 2$ 亿残 存する 肉芽組 織には，新生骨との間に多数の骨芽細胞がならび，盛ん に造骨機転がみえる (写真l1)。乙の傾向は離 開部位に よる差はなく，骨中央，鼻背側とも等しく行なわれてい る.エオジン好性の新生骨はすでに両骨切り端を連 結 し，骨性癒合の像を呈している。

固定70日：残存線維性結合 織の完全消失には至ら女 が、新生骨には骨梁の形成がみられ，その太さはいまだ 細い，また，骨䯣腔の形成もみられるが，骨道腔は拡大し ており，骨層紋す明瞭ではない。

固定100日：新生骨梁はほとんど完成し，多数みられ た造骨細胞，破骨細胞もその数を減じ，骨梁は厚く密に 形成されて扔り，骨化機転は完成に近づいている（写真 12).

(2) 緩徐拡大法

固定40日：一般に骨新生量は貧弱であり，口蓋側，鼻 背側と屯 anchoring callus, uniting callusを欠き, 離 開部の大半はいまだ結合織性成分によって占められてい る. 結合織内に形成された島嶼状の新生骨屯, その辺縁 には造骨細胞の量は少なく，両骨端の骨性䢒合への過程 は明らかに遅延している（写真13）。 また拡大床に相当 する口蓋粘膜直下には，リンパ球を主とす炎症性細胞浸 潤がみられ，さらに深部組織への拡大波及が認められ る.

固定70日：骨形成量は固定40日とほほ同様であり，一 部では骨性癒合むみられる。しかし大部分は線維性に骨 断端を連結し，炎症細胞浸潤はことに小骨片に著明であ
り，骨梁を破壊し，炎症性肉芽組織で置換されている( 写真14)。 また鼻腔粘 膜上皮 が離開 部の 新生骨に迷入 し，乙れを中心とした bone cyst を形成し，骨吸収し ているすのあみられた。

(3) 離開固定法

固定40日：いまだ一部には線維性結合織を残す部むみ られるが，骨と接する部では多量の造骨細胞の出現があ り，骨間隙の大部分は新生骨により充填されている.

固定70日：固定40日とは著差はなく，残存結合織は口 蓋より鼻背に至る帯状物となり，骨折線に沿ってわずか に認められる (写真15).

固定100日：口蓋, 賽側の一部には，般痕 化した結合 織をわずかに残すが，その他の大部分では新生骨による 骨充填はきわぬて旺 盛であり，骨の緻密化，骨梁の形 成, 骨髄腔の形成はほぼ完成骨汇近い像を思わせる（写 真16).

B）切歯, 犬䨑之その歯周組織について

(1) 急速拡大法

固定40日：前雪々髄は炎症性肉芽組織となり，著るし い炎症性細胞の浸潤をみる（写真17). その歯根膜腔は全 周にわたって拡大し，遠心部はことに著明である，拡大 した歯根膜空の歯槽表面には, 類骨組織の新生をみる. また根尖より遠心根中央にかけて，象牙質，セメント質 の軽度の吸収がみられる。

犬菡々髄には著変なく，象牙芽細胞その他の線維細胞 もほぼ正常である，象牙質，セメント質にあ何ら変化は 見い出されない，歯根膜は近心歯頸部に軗度の拡大があ るが, 主線維の走行は明瞭で, ほぼ正常像を示す.

固定70日：切歯々䯣は3 例中1例に正常像を示すすの があるが，その他ではいずれす壊死に陥り，炎症性肉芽 組織に置換されている，歯根膜は，近心側では主線維は 明瞭で，その走行も乱れることもなく，幅もほぼ正常で ある. 根尖部ではいずれも拡大傾向を示し, 同部に隣接 する歯槽底部は，外基礎層板は消失し類骨組織を著明に 形成する傾向を示している.

犬歯々髄に著変はみられず．歯根部では象牙質および セメント質の吸収が, 遠心側根尖部に軽度に認められる。 歯根膜腔は近心側は軽度の拡大を示し，同部には類骨組 織の形成がみられる．遠心側の根尖部では，主線維の走 行は明瞭で，歯根膜の湢もほぼ正常である.

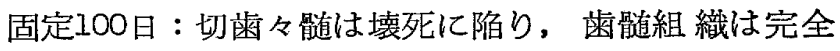
に消失し，肉芽組織で置換されている (写真18). 歯根 膜の幅は全周にわたっって正常であり，主線維の走行も明 瞭である．歯根遠心のセメント質の吸収がみられる症例 
では，象牙質が直接に歯根膜に接している.

犬雪は生活崡であり，歯䯣組織はほぼ正常である。象 牙質の近心側歯頸部では, 軽度の吸収がみられるものが あるが，逆に根尖から遠心にかけてセメント質肥厚を示 す症例むある，歯根膜腔は一般に拡大し，それは近心側 において比較的著明である，拢大部歯根膜には，類骨組 織の形成が著明である。

(2) 緩徐拉大法

固定40日：切歯々髄は壊死に陷る。歯根膜は，一般に 近心側の幅はほぼ正常であるが，主線維の走行は不明瞭 であり，根尖部では歯根膜腔の幅は桩大する．遠心側で は著明に拡大しており，根尖部菡槽底に存在する炎症巣 が歯根に波及して歯根膜の吸収融解は勿論, 歯根長 I/2 まで吸収しているすのあある，とのように全症例の㐘槽 底には炎症性肉芽が存在し，小骨片の骨梁を含めて前歯 々根の著明な吸収がみられる（写真19）。

犬歯々䯣の造牙芽細胞や歯骾細胞などには变化はみら れず，ほほ正常像を呈する，㐘根膜腔は一般伀大して おり，特に近心側は著明である，同部には造骨細胞の出 現が著るしく，正常な蒾根膜幅への復帰がみられる。

固定70日：切崡々䯣はいずれも壊死に陥り再生への機 転は全くみられない，歯根膜は唇側ではやや幅の拡大が みられるが, 主線維の走行は明瞭である。しかし歯根尖部 および遠心側の歯根膜は炎症性肉芽組織によってみたさ れるが, 炎症性変化が波及していない部分では骨梁の形 成は旺盛であり，骨離開部の骨性癒合を保っている。 犬雪々䯣に著変はない，蒾根膜腔は，固定40日に比して 拡大傾向を示し，ことに近心および遠心歯頸部で著るし く，外基礎層板を欠き，類骨組織の形成がみられる。

(3)離開固定法

固定40日：切歯々㖪は罗死に陷る，歯根膜腔は全周に わたって拡大しておりことに根尖部で著るしく，同部 にて骨䯣と交通するあのさえみられた。米根部は根尖部 でセメント質が，遠心歯頸部では軽度の象牙質の吸収が みられた，歯根膜の主線維は根尖部を除いては，比較的 明瞭であり，炎症などの異常所見は見出せない，歯根膜 と接する歯槽骨には，セメント質の吸収坴に一致して， 類骨組織の形成がみられる。

犬歯々䯣は, 変性菱縮を示す一部の象牙芽細胞層を除 いては，ほぼ健康組織であり，セメント質，象牙質にも 吸収あるいは肥大などの所見はない，歯根膜腔は近心側 で拡大がみられ，歯頸部でもっとも幅広くなっている外 は，遠心側，根尖部ともほぼ正常であり，歯根膜の主線 維の走行にも著変は認められない.
固定70日：買死に陥った切㐘々䯣の一部には。肉芽組 織の増殖がみられる。歯根膜腔では, 近心側に幅の拡大 があり，その歯槽壁には菲薄な新生骨の添加がある。 た遠心側根尖には，七メント質の吸収がみられ，同部に あ類骨組織の増生がある。

犬齿々䯣は冠部の一部に壊死像を呈するものの，その 他では歯䯣組䌃㲸著変はない，歯根部の象牙質，セメン 卜質にも著変はない，歯根膜腔は，近心蒾頸部から根尖 にかけて拡大し，同部に接する近心雬槽壁には類骨組織 が形成されているが，いまだ層板構造を示すには至って いない。根尖部および遠心側の䨑根膜幅, 主線維の走行 などには著変はない，しかし】例では近心侧歯槽壁には 破骨細胞が出現し，吸収過程を呈している.

固定”100日：切菡々冎道は肉芽組織でみたされており， 荬䯣の固有細胞は全く消失している。荬根膜腔は近心側 に軽度の拡大がみられるほかに著変はない，拡大部の雬 槽壁には類骨組織が形成されており，正常な歯根膜幅へ 復㴆している。しかしいまだ層板を形成するまでには至 っていない.

犬歯々䯣は一部に変性を示す部が認められるが, 象牙 芽細胞層, 線維細胞, 細血管などには著変なく, 全く健 康像を示す. 歯根部の象牙質, セメント質にも何ら変化 はみられない，歯根膜腔は一般に近心はわずか搪大して おり, その他では正常であり, 主線維の走行も明瞭であ る.

\section{IV 考察}

上下の顎骨間に前後的あるいは垂直的に大きな skeletal unbalance のある症例，すなわ真性下顎前突症 や著るしい上顎上突症あるいは開咬などでは，非観血的 矯正法だけでは䫟骨の大幅な変化を期待するにはおのず と限界がある。

従来行なわれてきた外科的矯正処置は，上顎骨や下顎 骨に量的な過成長がある場合に，その過剩部を切除し，

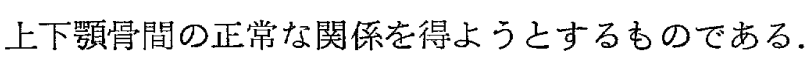

しかし前述したような種々なるタイプの反対咬合のう ちであ，下顎骨は正常であり，上頢骨に劣成長があるた めに上下顎の相対的な skeletal unbalance を招来して いる症例においては，観血的に上顎骨の前方移動を計る ことが絶対に必要な治療法であると考える。

さて生体の skeletal unbalance を観血的北修復する 方法としては，古くから整形外科領域で行なわれる下肢 延長術がある．すなわち種々なる疾患によって骨組織の 劣成長や短縮があるとき, 患肢に横骨折を起こして人工 
的に離断し，同部を機械的に離開させて，畹開部が新生 骨で充填されることにより下肢の延長を完成させようと するもので，既に多くの臨床例も報告されている(30 42)

しかるに上顎骨を観血的に拡大延長する方法について は, 同部の解剖学的複雑さや，韭薄なる骨質で構成され ているために危惧される骨修復への不安の故にか, 全く 等閑視されてきた.

従って上頡骨を観血的に離断，拡大しょうとすると き，骨離開部掞よび歯牙，歯周組織を含む小骨片がどの ように修復され，変化していくかその機序を知ること は，今後の観血的矯正法を確立するために，最も基本的 な問題であると考えられる.

そこで著者は，上顎骨の観血的矯正法における基本的 諸問題を解決するため, 動物を用いて実験的な研究を行 った. 以下実験内容に関して 2,3 の考察を加える.

(1) 肉眼所見を模型計測について

拡大速度,方法の違いを問わず，3方法中いずれにおい てあ小骨片は前方移動のみでなく，上方へあ傾斜する傾 向を有していた。しかしての骨片の上方転位は，1回の

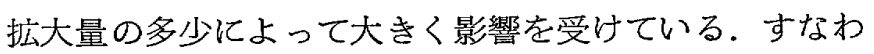
$50.2 \mathrm{~mm} /$ 日の緩徐拡大法でも, また一時に平均 $4.5 \mathrm{~mm}$ 拡 大して固定した離開固定法でも, 骨折端の離開形態は楔 状を呈するに至った。乙れは骨折端に加える拡大力を, 崡牙を介して行なったため，口蓋側にはより強い直接的 な離開力が加わり，鼻背㑡では周囲を被う軟組織のため 拡大力が減弱され，そのため拡大幅が小さくなる。ささ に咀嚼時に加方る下顎前歯の上方へのベクトルが小骨片 の上方転位を助長したものと考える. てのような現象 は，実際の臨床では 開咬状態をひき起すことになり， 本法が骨や歯牙の合目的的方向への移動という治療目標 にある以上，絶対に回避すべきことであろう。これに対 して0.7mm/日の急速拡大法では, 骨片がやや上方へ転位 する傾向がみられはしたが，3方法中で最も転位は少な く，汃幅広く前方拡大を行ない得た．従ってその顎骨 を被う鼻孔および上口唇を含む軟組織も術後に“高まり” を得ることができた。これは上顎骨の劣成長を有する反 対咬合に特徵的にみられる“中くぼみ”型の改善に対し てあ大きな期待を与えるものである.

模型計測によると，器械的拡大による骨折端の離開量 は，急速拡大法で得られた $12 m m か ゙$ 最大であり，最小は手 指で離開させた離開固定群の2.0mmであった．ての最大 離開量は20日間の動的期間で得られた值であり，骨折端 の拨大量は搪大ネジによる器械的な漸次法が, 手指によ る拡大法よりも顎骨の劣成長に対する有利な方法となり
得るあのである.

一方小骨片の前方拡大の反作用を受ける上顎左右の犬 歯の遠心移動量は, 最大 $2,5 \mathrm{~mm}$ (緩徐拡大法), 最小 $\mathrm{Om}$ (3方法とも)であった。乙れら反作用による遠心移動量 の平均值は, 緩徐拡大法 $1.2 \mathrm{~mm}$, 急速拡大法1. Omm そして 離開固定法0.4mmの順之なる. 故に上顎左 右犬歯の遠心 移動量は骨切り端に拡大時に加わる力の強さ（拡大量の 大きさ）に逆比例する之言える，すなわち強過ぎる力 は，歯を動かすには不適当であり，弱い力こそが崡牙移 動の根源となり得るという臨床的事実と一致するすので ある.

\section{(2) $\mathrm{X}$ 線学的所見について}

骨切り後に骨折端に牽引力を加えた場合の X 線学的所 見については，多くの報告があり，仮骨形成に対する影 響に関しても論議の絶えない現状である．たとえば，河 野44)は家兔の脛骨に横骨折を起こさせ，骨折部に種々な る固定法を施して骨折治療状沉を観察した。 その結果率 引力を加えた骨折断端の仮骨形成は不良であると述べて いる.一方丸毛45)らは家兔を用いて，1日.10mm〜2.0mmづ つの 2 週間の漸増的な率引力による拡大を行ない，脛骨 長の10\%の延長を行った結果, 術後 2 週間で仮骨が出現 し，4週間ではさらに著明となり，12週で骨髄の形成を 認める程良好な結果を得たと報告している．また篠田46) も成犬下腿埧切り予定線に沿って十分な筒状の骨膜剥 難を行って, 延長器に上って術直後 $4 \%$, 術後 3 日に 3 $\%$, 術後 5 日目に $3 \%$ と合計 $10 \%$ の間歇的な漱增力によ る延長術を施行した，その結果，骨延長部は，拡大初期 から出現する uniting calllus, その後に増量してくる外 骨膜性のanchoring callusおよび両側の anchoring callus を結合する bridging callusにより充たされ，率引力は 骨再生機転に対し極好有効であるて之報告している.

種々な率引力を加えた本実験の上顎骨に拈ける仮骨形 成は次のようであった，すなわち漸次的な拡大法のうち で屯, 比較的短時日（20日）の動的期間であった急速搪 大法では, 固定後70日目では拢大部の類側中央の一部を 除いては，大部分が骨端部より伸展してきた uniting callus に充たされ，既便化像を呈するに至っている. 固定後100日目では透過像は最早みられず，仮骨の大部 分は硬化を示し, 在来骨との境界む判然としなくなって いる. 一方器械的な拡大による動的期間を長期 (40日) にした緩徐拡大法では，1回の拡大量が少なかったにあ かかわらず，固定40日に至るも骨折端での架橋は一部に みられるにすぎず，仮骨形成は遅れている．固定70日で は, 離開部の X 線透過像は一層顕著になり, 骨破壊像を 
呈し，それは小骨片の䨑槽骨にも波及して抢り広範围の 骨吸収を思わせる。

このように上顎骨の漸次的前方拡大実験においては， 急速拨大法では平均離開量は最大（平均 $10.0 \mathrm{~mm}$ ) であっ たにもかかわらず極めて順調な仮骨形成が認められた。 これに対し緩徐拡大法では，固定日数の増加とと屯に仮 骨形成量はむしろ減少している。とのとよより骨離開部 に対する仮骨増生の良否は，拡大量よりむしろ拡大日 数，すなわち動的期間の長短㮫接な関係があると思わ れる。

漸次的拡大法によらずに，一時に最大の拡大を計った 離開固定法では，他 2 万法に比し拡大量が小さく，かつ 平行拡大を目論んだにもかかわらず鼻背側を頂点とした 楔状拡大が行なわれていた。従って仮骨の補填は少量し か要しないためか，固定後40日目で㲽縁は架橋され，極 ぬて良好な仮骨増生をみながら，固定後”100 日目では骨 㾉合ほぼを完成していた．3方法之もの仮骨形成は外骨 膜性のanchoring callus はほとんどみられず，主として 内骨膜に由来する uniting callus による離開部の充填 が大部分を占めていた。

(3) 病理組織学所見について

正常な骨折治癒機転が，骨折断端に加わる種々なる外 的. 内的条件により変化し47)質的，量的あるいは形態的 にも影響を受けることは当然考えら机るところである。

Eggers ${ }^{48}$ ) は骨折端に圧抵抗を加えた之きの仮骨形成 についての病理組織学的検索を行い, contact-compression が仮骨分化任好都合である之述へ，藤原49）は 骨折端に抽ける種々なる物理的条件下で, 弱い率引力が 最む好ましい影響を与えると結論している。 Weinmann 43)は強力な率引力は骨の吸収，破壊をきたすが，一定限 度内では骨の添加は増大すると述べている，また河野44) は骨折端に種々の固定条件を賦与した実験を行ない，骨 折治癒は固定条件如何によって影響されるあのであり， 正常治癒, 遷延治癒あるいは病的治癒まで各種の傾向を 認めている.

著者は可及的同一条件下においた上顎骨の骨折端に牽 引力という外的物理的因子を, 漸次的执上び一時的に与 えることにより生じた骨離開部および周囲組織の変化に ついて病理組織学的検索を加えた.

まず骨離開部の所見として，固定日数が同じであって 屯，急速拡大法之緩徐拡大法とでは仮骨形成に著差を生 じた。すなわち急速拡大法の固定40日目でみられる離開 部の残存肉芽組織の楇辺には，旺盛な造骨細胞の増殖が みられる. 固定70日目では，肉芽組織部 分は狭少とな
り，かつ肉芽組織内の各所に骨梁の形成をみるようにな る. 固定日100日目で，その骨梁は太く密となり，ほと んぞ完成した骨組織を呈する。－一方動的期間に 2 倍の時 間を要した緩徐拡大法では，著しい骨瘉合の遷延がみら れる，すなわち固定期間が40日目では骨肉芽の形成は弱 く, 離開部の仮骨および在来骨は吸収されて肉芽組織に よって置換されている，70日目では，遂に口盖骨に瘦孔 を形成するに至るが，1例では鼻路との交通を思わせを 鼻腔粘膜上皮が拻入し，それを中心とする bone cyst を形成するものむみられた。

また一時的に最大に拡大した離開固定法では，固定70 日目では既にほとんど新生骨で充填され，固定 100 日目 では新生骨に骨梁の形成もみられ離開部の骨化は完成像 を思わせる.

以上実験 3 方法による骨離開部の病理組織学的所見は 前述したX線像の所見と一致しそそれを裏付けるもので ある.すなわ占骨離開部の修復機転は動的期間が短かか った急速拡大法と離開固定法が良好な結果を示した。し かし長期の動的処置を行った緩徐抬大法では，骨䯣炎や 㿉孔形成を伴ない。著るしい骨性治癒の遅延を来たした。 この急速拡大法での上顎骨の所見と，長管骨におりる骨 延長実験とを比較してみる之，後者では篠田46)の成犬下 肢延長術でみられた如く anchoring callus の多量の增 生をみたこと以外では，骨性癒合の時期および状態は極 めて類似した結果であり，また丸毛45)の家兔での下肢延 長実験における仮骨形成所見と屯同様所見を呈してい る。これらのことから上顎骨々折端部には率引力（ただ し急速㹡大法）は有効化作用するものと考えられる.

ついで外科的に切断された小骨片の切歯々䯣の生死問 題むなおざりにされない点であろう．急速拡大法に例外 的にみられたI例の生活歯䯣を除いて，3方法いずれに おいても歯髄組織は炎症性肉芽組織により置換されてお り, 雪䯇組織への再生の機転は認められず，却って般痕 化を示した。このような歯䯣所見は，上顎骨一部切除術 に際しても周囲からの血流灌入があり，歯髄の生活力は 保たれるという Walker 50)や Obwegeser51) の説，ある いは骨切りが歯根尖より $0.5 \mathrm{~cm}$ 以上離れていれば，その 間にある吻合より歯䯣への血流によって歯䯣の循環は継 続されるという Bell 52) の説等之対立するあのである.

しかしかれらの実験は, 何れも上䫇骨切除後直与に整 復固定されたものであり, 切歯々䯣を栄養する前上歯槽 動脈系の再循環は比較的容易に行なわれたことが想像さ れる.しかし本実験においては,上靧骨離断後経時的に率 引し，あるいは離断直後に骨折端を離開固定したもので 
ある.そのため前上崡槽動脈の切断端の接合は著るしく 遅延し，骨折部創面は比較的長期にわたって開放され， 催炎性刺激，特に細菌の侵入は必然的に起こるあのと考 えられる. 勿論前霜部䨑䯣ならびに蒾周組織のいづれも がその可能性をもつものでる。しかし雬骾組織は主とし て前上歯槽動脈のみの支配を受けて扣り，また比較的㓜 弱な間葉性組織であるため，特に被害状態に宿りやすい ものと考える.いずれにせに,本法の臨床的応用に関して は，畨髄の根管充填の併用を余儀なくさせることを示唆 する所見であるう。

切歯々根のその支持組織においては，急速抎大，離開 固定の両方法とも根尖部遠心側に軽度の吸収があり，歯 根膜腔，ことに遠心側は一般に拡大する傾向を有する。 これは前方拡大力により切歯が歯槽内で唇側傾斜した影 響であると考えられる．しかし固定期間が増加するにつ れ，䨑槽壁の表層では類学組織が形成され固定 100 日目 では歯根膜は正常幅に復帰している。緩徐拡大法では骨 端離開部から波及した小骨片への炎症が，切歯々槽骨の 吸収をむ惹きおこし，炎症性肉芽組織を形成しながら遂 には曾根長 $1 / 2$ 迄に至る高度の破壊吸収像を示してい る.

このととから切雨々根拈よびその支持組織に及ぼす牽 引の影響は，動的期間が長期にわたるものでは著しいと いうととがわかった。

小骨片の前力拡大に対する固定源之なる上顎大歯では ，象牙芽細胞などの歯䯣組織は.いずれの方法におういてす 殆んよ゙著変はみられない。また象牙質, 七メント質は急 速拡大法の固定 100 日目で歯頸部近心に軽度の吸収がみ られたが, その他の症例では著見はみられない，歯根膜 腔は各方法と手近心側は遠心側に比し拡大しており, 主 線維の走行も不明瞭であり犬歯の遠心傾斜の所見を呈し ている．固定70日目に達すると，いずれの方法におい て屯歯根膜拡大部の粕槽骨最表層には，類骨組織や線維 の再配列がみられ，比較的早期に正常像へ回復する傾向 があった．乙のように固定歯に対する拡大力の反作用の 影響は，いずれの方法において屯軽徽で，しかも早期に 安定に向うものである。

以上，上顎骨少成長に起因する下顎前突症に対して， 観血的矯正法を導入するために，成犬を用いて実験を行 った成績について述べたのであるが，本実験の臨床的応 用の可能性は充分あるあのといえよう。しかして急速拡 大法, 緩徐拡大法, 離開固定法と屯に仮骨形成は骨折端 からの, 主として uniting callus の形成により離開部は 充填されるのであるが，拉大法の違いによって治癒像に
は著るしい相違がみられる。

まず離開部の骨性治癒状態は，急速㹡大法および離開 固定群においてほぶ同様の所見を呈し，固定 100 日目で 骨性瘉合は完成する。しかし離開固定法は離開量が少な く，かつ小骨片の上方傾斜の傾向が強いため良好な方法 であるとはいえない.また急速抾大法においては，切崡部 および犬歯の霜牙そのものや畨周組織に及ぼす悪影響す 最む少く，汃つ拡大量む平均10.0 mm 23 方法中最大であ る.この結果上顎骨の“中くぼみ”は改善され,所謂反対咬 合に対する治療の目的屯充分達成され得るものである.

固定を行った約 100 日間で骨折部位の骨形成は完了す るが，これによって小骨片の位置が固定床除去後に安定 するとは限らないすすなわち小骨片の前方移動によっ て緊張された骨膜, 歯肉および周囲諸筋などにより後戻 りする可能性があるからである。それらの適応性は移動 量の大小，ならびに個体の相異などの多くの条件によっ て影響をうけるあのであり，ての問題は今後の研究にま つ必要がある，しかし本実験は反対咬合者の治療が主目 的であるから，反対の被蓋が正常な被蓋になれば，自然 にその位置に保定されるので，固定床を使用したし同じ 結果を生じ，上頡骨は安定され，改めて特別な人工的装 置による固定期間は必要としないと考えられる.

要するに上䖀骨の前方拡大の成否には，骨折端離開時 の動的期間が密接に関連していることがわかり，一定限 度内の拡大量であれば動的期間は短か心事が必要である し，さらには所謂反対咬合に対する観血的矯正法は有効 な治療手段になり得ることを強調したい。

\section{$\mathrm{V}$ 結}

上顎骨の少成長に起因する所謂反対咬合の観血的矯正 法による新しい治療法を開発するため，成犬の上顎骨に 人工的に骨切りを行ない，拡大ネジで前方拡大して，次 の結論を得た。

1）上顎骨の前方搪大量は，急速桩大法が最大 $12 \mathrm{~mm}$, 平均 $10 \mathrm{~mm}$ ，続いて䜌徐拡大法の最大 $8.0 \mathrm{~mm}$ 平均 $7.5 m m$ であ り離開固定法では最大 $4.5 \mathrm{~mm}$, 平均 $3.6 \mathrm{~mm} ゙$ あった。

2）骨端離開部の新生骨は uniting callus を主体と するあのであり，骨性癒合は急速拡大法，離開固定法， に扎て，固定100日でほぶ完成した，一方緩徐拡大法 では，たえず加わえられる芽組織への刺激のためか，却 って著るしい骨性治癒の遷延を招来した.

3）骨折端桩大部の離開形態は，急速拡大法ではほ心゙ 平行であり緩徐拡大法, 離開固定法では楔状を呈し, 小 骨片は上方へ転位する。 
4） X 線所見と病理所見ととはよく一致し，新生骨の 増生状況の把握を容易にし，骨性治癒時期の判定に際し て有効な手段となる。

5）上䪽切菌に対する影響は，歯䯣では急速拡大法の 工例を例外として，桩大法の差異を問わず全症例肉芽組 織に置換していた。また䨑根部では緩徐拡大法では, 䨑 槽底の炎症性肉芽組織により著しい歯根の吸収をみた が，急速拡大法，離開固定法では，象牙質，セメント質 の軽度の吸収を認めたにすぎなかった，また歯根部は小 骨片内で僅かに唇側倾斜し, 舌側曾根膜の拡大傾向を示 したが，固定100日目ではほぼ正常幅に復した。

6) 固定歯である上顎犬宷への影響は，いずれも軽微 であり, 最大 $2.5 \mathrm{~mm}$. 最小 $0 \mathrm{~mm}$, 平均 $0.4 \mathrm{~mm}$ の遠心移 動を示した. 歯骮組織, 歯牙支持組織には著変はみられ ず，拡大法の違いによっても著差は認められなかった。

以上のことから急速拔大法は, 観血的矯正法による上 顎骨前方拡大.の最む有効なる手段となり得ることが証明 された。

（和を終えるに当り, 終始御指導, 御校閲を賜水った 恩師横田成三教授, 並びに御愁篤な御指導, 御校閲を頂 いた本学病理学教室浦鄉篤史助教授に梁甚なる感謝の意 を探げる．また实験上適切な御教示を頂いた病理学教室 航越啓右溝師に表心上り謝意を表するととるに，同教室 㝓位の”."援助に深く感謝する。)

本論文の要旨は

昭和45年10月 9 日 第29日回本矯正歯科学会総会で発 表した。

昭和46年.9月14日 九州歯科学会例会で発表した.

$$
\text { IV 文献 }
$$

1. 高橋新次郎; 新編歯科矯正学 : $12-23$, 永末書店 ( 京都), (1965).

2. Graber, T. M ; Orthodentics, Principle and Praticce, 2 nd ed., 204-205, W. B. Saunders Co., (1967)

3 須佐美隆三，尾関哲也; 下靧前突者の実態 : 日矯歯 誌, 25, 271-272, (1960).

4. Wallace, J. S. ; Variation in the Form of the Jaws : London, Basillier, 155, (1927).

5. Hellmann, M. ; Morphology of the Face, Jaws and Dentition in Class III Malocclusion of the Teeth : J. A. D. A., 18, 2150-2731, (1931).

6 . Moore; Heredity as a Guide in Dento-Facial Orthopedics : A. J. O. O. S., 30, 549,
(1944).

7. Broadbent, B. H. ; A new $X$-ray tecnique and its application to Orthodontia : Angle Orthodontist, 1, 45-66, (1931).

8. 䉼川 浩; 所謂反対咬合の形態学的研究第 3 編レン トゲンセファロメトリーによる研究 : 日矯歯誌, 20, 170-191, (I961).

9. 山口明; 所謂反対咬合のレントゲンセファロによる 形態学的研究 : 九州霖会誌, $14,342-560$, (1960).

10. 須佐美隆三; 下顎前突者の䭭顔面頭蓋形態の年齢的 推移に関するX線計測学的研究 : 日矯歯誌, 26 ( I ), 1-34, (1967).

11. Lundsrtöm, A. F .; Malocclusion of the teeth regard as a problem in connection with the apical base : Int. J. Orthod., 11, 1109-1135, (1925).

12. Weinberger, B. W. ; Orthodontics an historical review of its origin and evolution. 1, 424429, Mosby (St. Louis), (1926).

13. Krebs, A. ; Expansion of the midpalatal suture. studied by means of metallic implants : Acta odont. scandinav., 17, 491-501, (1959).

14. Haas, A. J. ; The treatment of maxillary deficiency by opening the midpalatal suture : Angle Orthodontist, 35, 200-217, (1965).

15. Brückl, H. et al. ; Nachuntersuchung behandelter Schmalkiefer : Fortschr. Kieferorthop., 23, 355-365, (1962).

16. Costa del Rio, D. ; Untersuchungen über das Rezidiv der transversalen Expansion, Fortschr. Kieferorthop., 23, 359-400, (1962).

17. Stahl, A. ; Zur Frage des Rezidiv bei der Behandlungen des ${ }_{\AA}^{-S c h}$ malkiefer : Fortschr. Kieferthop., 23, 345-354, (1962).

18. Isaacson, R. J. et al. ; Some effects of rapid maxillary expansion in cleft lip and palate patients : Angle Orthodontiist, 143-154, (1964).

19. Lebret, L. M. L. ; Changes in the palatal vault resulting from palatal expansion: Angle Orthodontist, 35, 97-105, (1965).

20. Haas, A. J. ; Palatal expansion : Just the beginning of dento-facial orthopedics: Am. J. Orthod., 57, 219-255, (1970). 
21. 松本 稔, 吉井修; 正中口蓋縫合の離開による顎の 側方桩大を応用した 1 治験例 : 日矯雪誌，27，166 -174, (1968).

22. 鈴期祥井他; 拡大ネジIII. 症例, 日矯歯誌, 28 , 146-162, (1969).

23. Debbane, E. F. et al. ; A cephalometric and histologic study of the effect of orthodontic expansion of the midpalatal suture of the cat : Am. J. Orthod., 44, 187-219, (1958).

24. Haas, A. J. ; Rapid expansion of the maxillary dental arch and nasal cavity by opening the midpalatal suture : Angle Orthodontist, 31, 73 90, (1961).

25. Burstone, C. J. ; Sutural expansion by controlled mechanical stress in the rat: J. dent. Res., 38, 534-540, (1959).

26. Cleal, J. F. et al. ; Expansion of the midpalatal suture in the monkey : Angle Orthodontist, 35, 23-35, (1965).

27. Starnbach, H. et al. ; Facioskeletal and dental changes resulting from rapid maxillary expansion : Angle Orthodontist, 36, 152-164, (1966).

28. 清水達夫; 器械的刺激の煩骨発育に及ぼす影響につ いて：口科誌，17，251-257，(1968).

29. 小杉緑朗; 猫上顎骨側方拡大に関する害験的研究 : 口病誌, 36, 223-245, (1969).

30. Condivill1, A. ; On the means of lengthening, in the lower limbs, the muscles and tissue which are shortend through deformity : Am. J. Orthop. Surg., 2, 353-369, (1905).

31. Freiberg, A. H. ; Condiviall's method of lengthening the lower extremity : Surg. Gyne. and Obst., 14, 614-617, (1905).

32. Putti, V. ; The operative lengthening of the femur : J. A m. Med. Asson., 77, 934-935, (1921).

33. Abbott, L. C, ; The opertive lengthening of the tibia and fibula: J. Bone and Joint Surg., 9, 128-152, (1927).

34. Barr, T. S. and Ober F. R. ; Leg lengthening in Adults : J. Bone and Joint Surg., 15, 674678, (1933).

35. Bosworth, D. M. ; Skeletal distraction of the tibia : Surg. Gyne, and Obst, : 66, 912-924,
(1938)

36. Moore, B. H. ; A critical appraisal of the leg lengthening operation: Am. J. Surg. 52, 415423, (1941).

37. Allan, F. G. ; Operative lengthening of the lower extremity : J. Bone and Joint Surg. 30B, 490-505, (1948).

38. Bost, F. C. and Larsen, L. J. ; Experiences with lengthening of the femur over an intramedullary rod : J. Bone and Joint Surg., 38-A, 567-584, (1956).

39. Sofield, H. S. ; Leg-lengthening : J. Bone and Jint Surg., 40-A, 311-322, (1958).

40. Blount, W. D. and Glaske, G. R. ; Control of bone growth by epiphyseal stapling. : J. Bone and Joint Surg. , 3l-A, 464-478, (1949).

41. Compere, E. L. ; Indications for and against the leg-lengthening operation : J. Bone and Joint Surg. , 18, 692-705, (1936).

42. Smart, B. W. ; Problems of leg length equalization : Postgrad. , 37, 348-353, (1965).

43. Weinmann; Healing of bones : Bone and Bones, 314-323, Mosby Co. (St. Louis), (1955).

44. 河部通忠; 生物学的見地よりみたる骨折治癒：日整 会誌, 29，567-585，(1955).

45. 丸毛英二他; 下肢延長に関する臨床ならびに動物実 験：日整会誌，39，530-532，(1955).

46. 篠田之秀; 下肢延長術に括ける骨修復過程の実験的 研究：札幌医誌，30 (2/3)，140-163，(1966).

47. 吉村義之; 仮骨 分化の実験病理学的研究：日整会 誌, 26, 73-88, (1952).

48. Eggers ; Clinical significance of the compresssion factor in bone surgery : Arch. Surg. , 2, 467, (1951).

49. 藤原由利夫; 骨格筋トーヌスの骨折治癒に及ぼす影 響に関する実験的研究：日整会誌，36，305-317， (1962).

50. Murphey, P. J. and Walker, R. V. ; Correction of maxillary protrusion by osteotomy and orthodontic therapy: J. Oral Surg. Anesth. Hosp. Dent. Serv. , 21. 275 .(1963).

51. Obwegeser, H. ; American Society of Oral Surgery comprehensive conference on oral surgery : Walter Reed Army Medical Center, Washington 
DC, (1966).

52. Bell, W. H. ; Revascularization and bone healing after anterior maxillary osteotomy : a study using adult rhesus monkeys : J. Oral Surgery, 27, 249-255, (1969).

\section{〔附図説明〕}

図1：ネジ付き拡大床(側面)
R. P : レジン床
E. S : 拡大ネジ

図 2 : ネジ付き拡大床（咬合面）

因 3 : 仮骨の分類（Weinmann による)

(1) Anchoring Callus (2) Bridging Callus

(3) Sealing Callus (4) Uniting Callus

図 4 : 急速桩大法に上る術前, 術後のX線写真重和合 わせによるトレーシング

実線：術前 点線：術後

図 5 : 緩徐桩大法による術前, 術後の X 線写真重和合 わせによるトレーシング

実線：術前, 点線：術後

図 6 : 離開固定法による術前, 術後のX楾写真重的合 わせによるトレーシング

実線：術前, 点線：術後

\section{〔写真説明〕}

写真 I：術前に前歯部は反対咬合をしている.

$2: \mathrm{I} 3 \sim \mathrm{C}$ 間は拡大され，反対咬合は改善されて いる。

3 : 急速拡大法, 固定40日離開部の淡い雲状陰影

4 : 急速拡大法, 固定70日離開部に出現した多量 の uniting callus

5 : 急速拡大法, 固定100日離開部の骨性痛合ほ 涩完成

6 : 䌅徐拡大法, 固定40日 離開 部は透過像を呈 し，仮骨の出現は少ない。

7 : 緩徐拡大法, 固定70日離開部の透過像は小骨 片にもおよび，前歯根尖にあ吸収を思わせる 透過像がみられる。
8 ：離開固定法, 固定40日離開部には旺盛な uniting callus 増生をみる。

9：離開固定法, 固定70日透過像は骨折端離開中 央部に一部残存するのみで，良好な仮骨形成 がみられる。

10 : 離開固定法, 固定 100 日離開部の仮骨は硬化 し，骨性瘜合の完成像である。

11. 急速拡大法, 固定40日, 肉芽組織周辺には旺 盛な造骨細胞の出現があり，造骨が行なわれ る(H-E 染色, $\times 50)$

12 : 急速拡大法, 固定 100 日, 離開部の新生骨に は骨䯣の形成がみられ，離拡部の修復はほ之 んよ゙完了された状態を示す.（H-E 染色. $\times 50)$

13. 縟徐桩大法, 固定40日, 離開部の大部分は肉 芽組織によって占められ仮骨量は少なく，島 嶼状に出現した新生骨周辺の骨芽細胞も少な W. (H-E 染色, $\times 50)$

14 : 緩徐拡大法, 固定70日, 離開部表層は溃瘍を 形成し，潰瘄縁には炎症性細胞の著るしい浸 潤がありままた骨組織は炎症性肉芽組織によ って吸収される。（H・E 染色， ×50）

15 : 離開固定法, 固定70日, 離開部は旺盛な仮骨 の増生があり，一部残存した線維性結合織の みである。（H-E 染色， ×50）

16 : 離開固定法, 固定 100日, 新生骨には骨䯣控 の形成が始まり，離開部の修復は完了に近い 状態を示す.（H-E 染色, $\times 50)$

17 : 急速拡大法, 前歯々䯣, 固定40日, 歯䯣は炎 症性肉芽組織によって置換される。（H-E 染色, $\times 50$ )

18 : 急速拡大法, 切霜々骾固定 100 日, 炎症性肉 芽組織は㿍痕化し，一部には石灰化を示す部 あみられる。（H-E 染色， ×50）

19 : 緩徐拡大法：切歯々根，固定40日，歯槽底部 炎症性肉芽組織の増生にともなう切雪々根の 著明な吸収。（H-E染色， $\times 50 ）$ 
Q 1

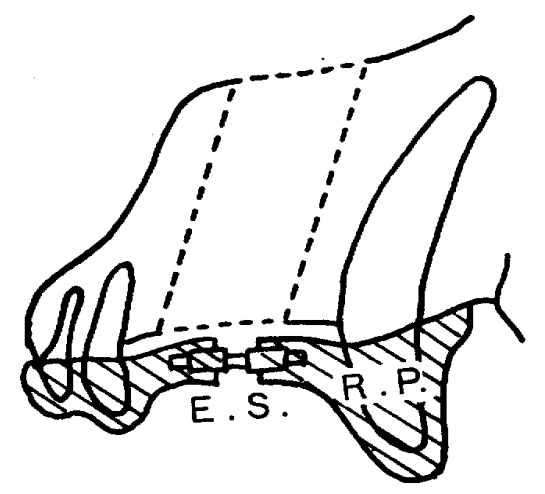

因 2

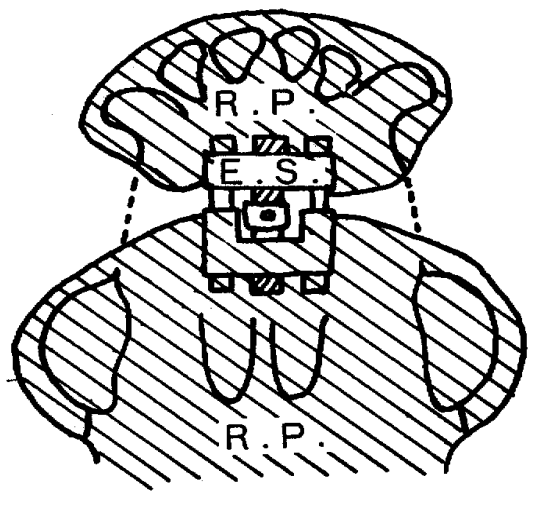

図 3

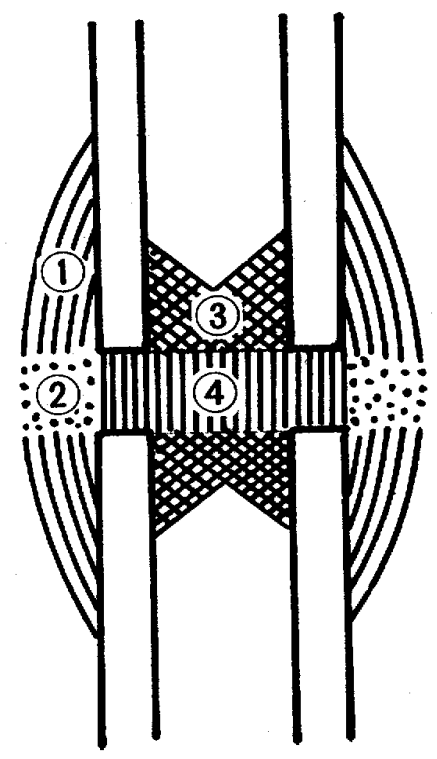

図 4

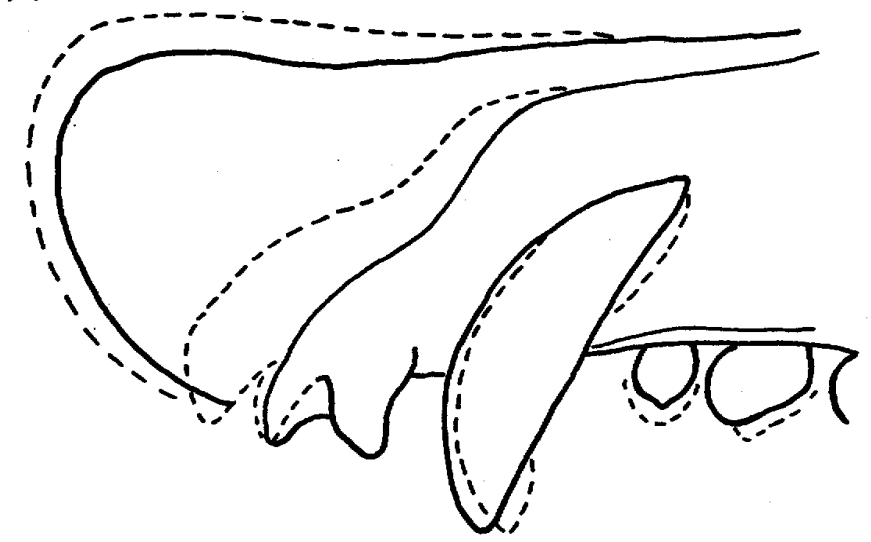

図 5

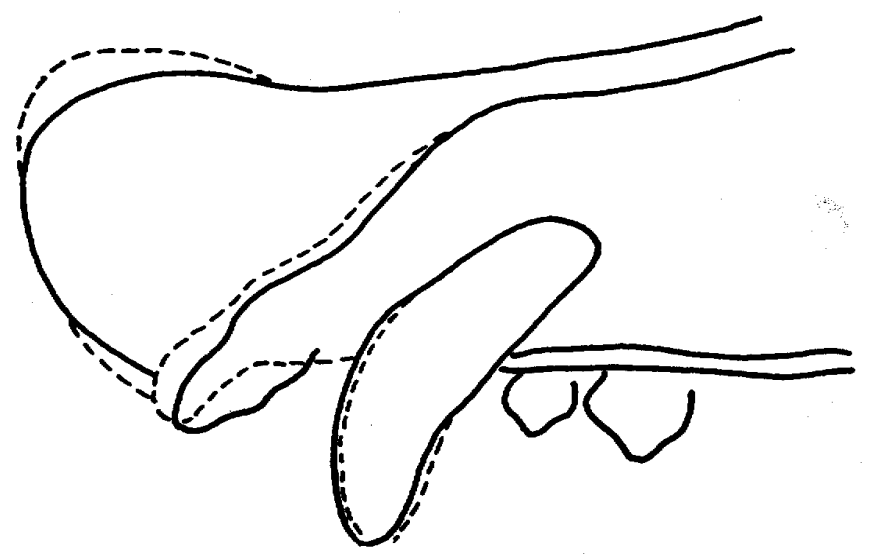

図6

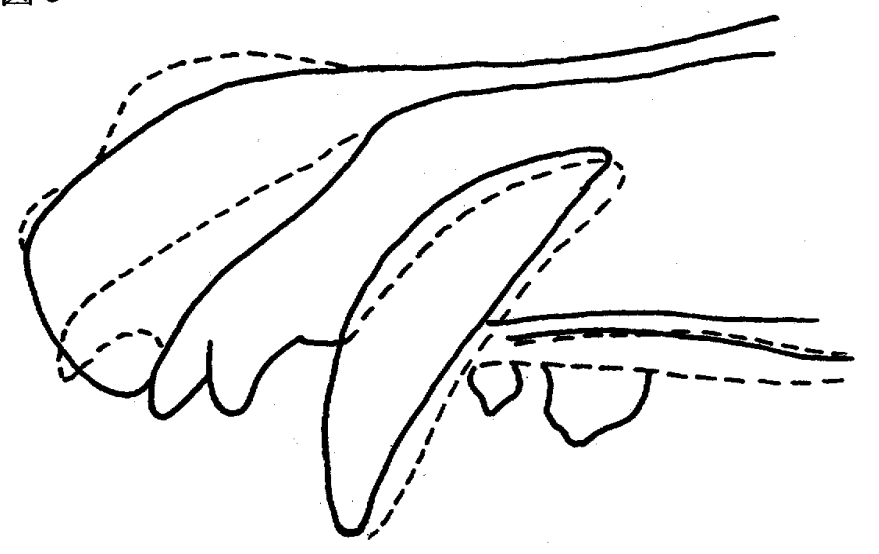


写真 1

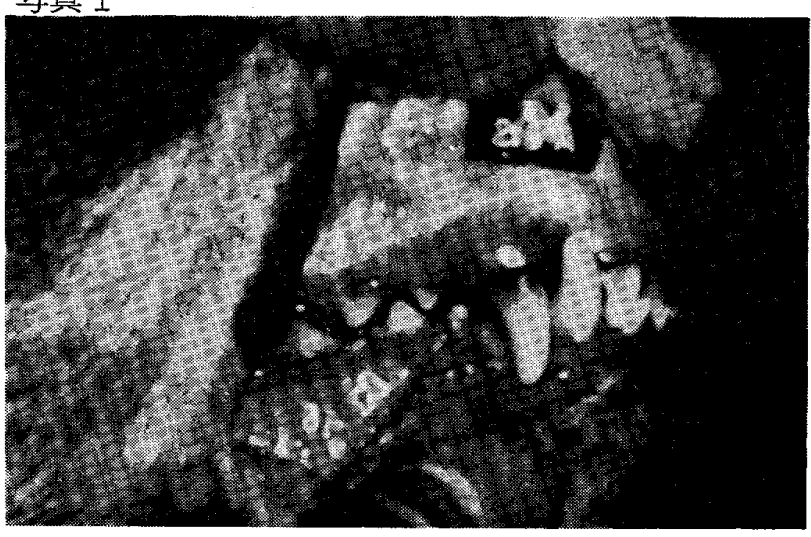

写真 2

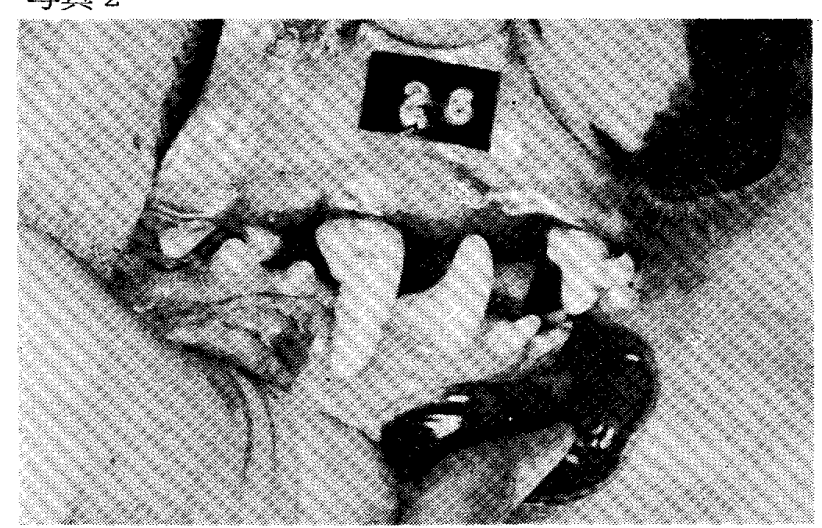

写真 3

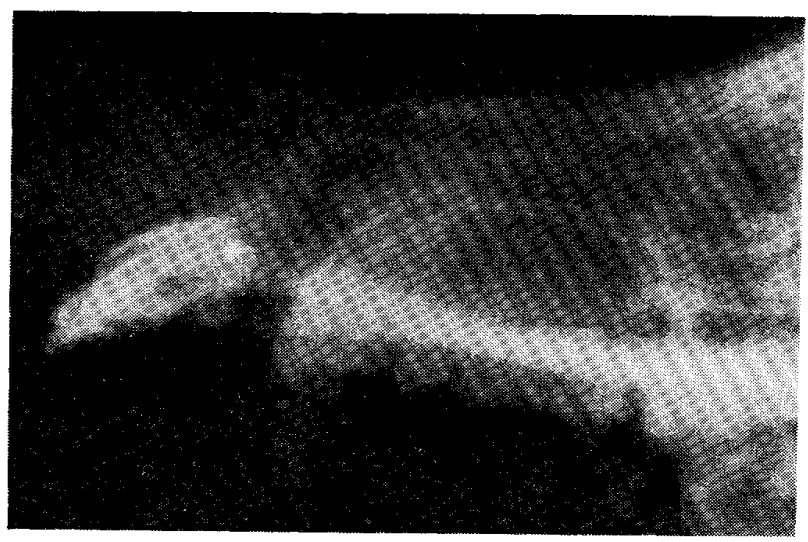

写真 4

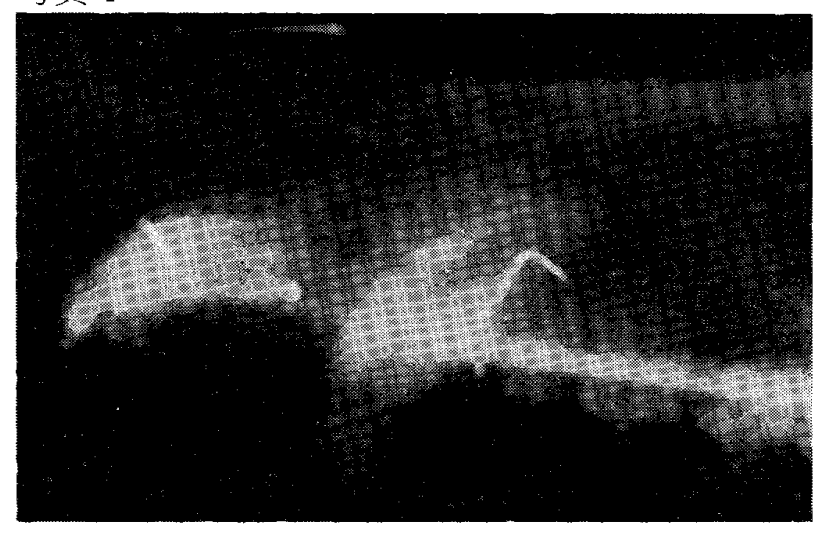

写真 5

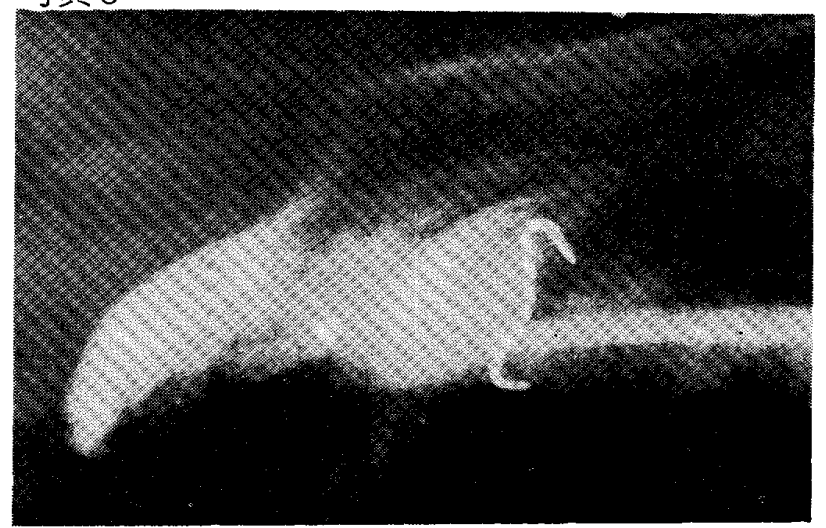

写真 6

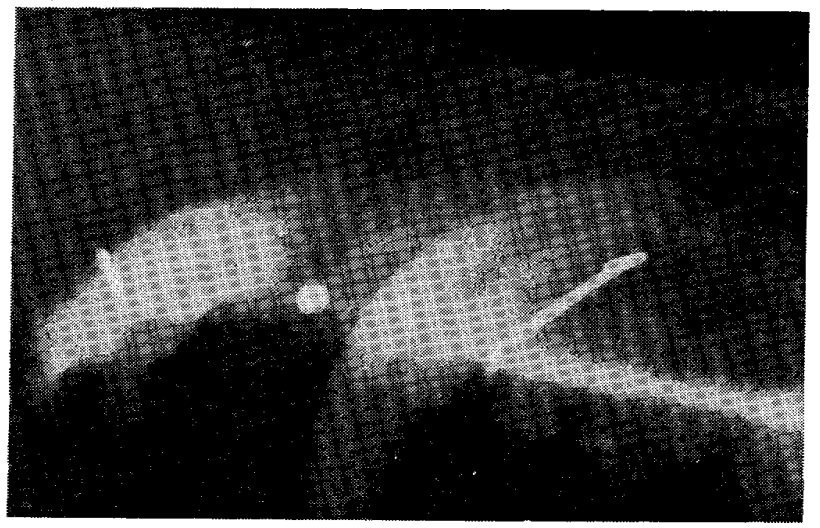

写真 7

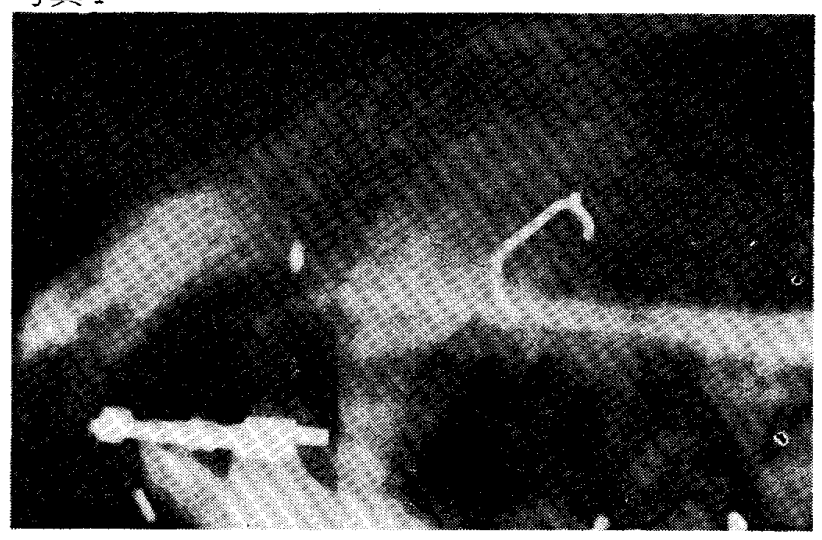

写真 8

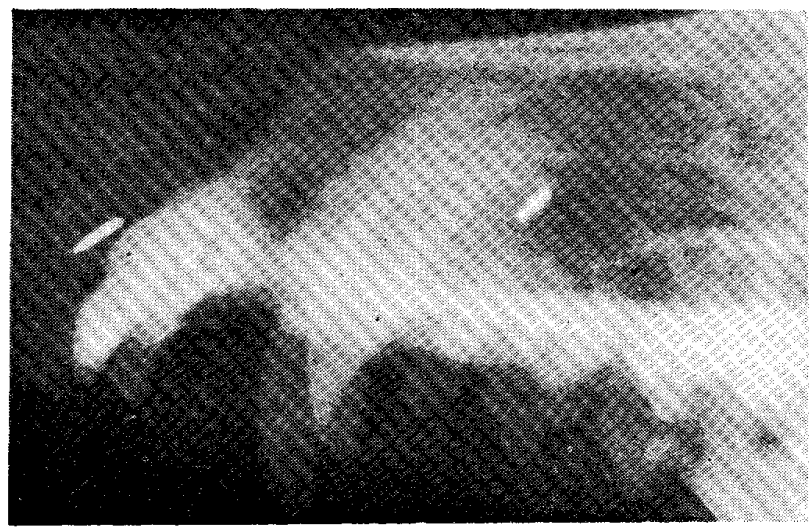


写真 9

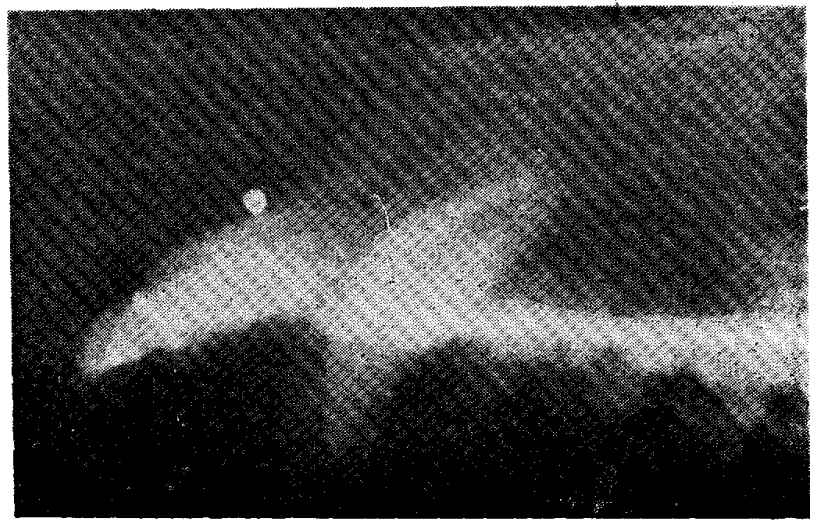

写真10

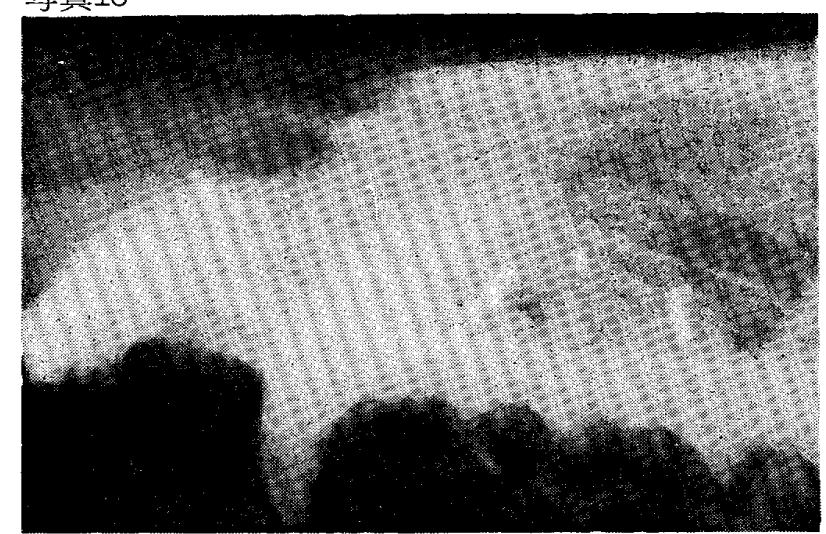

写真11

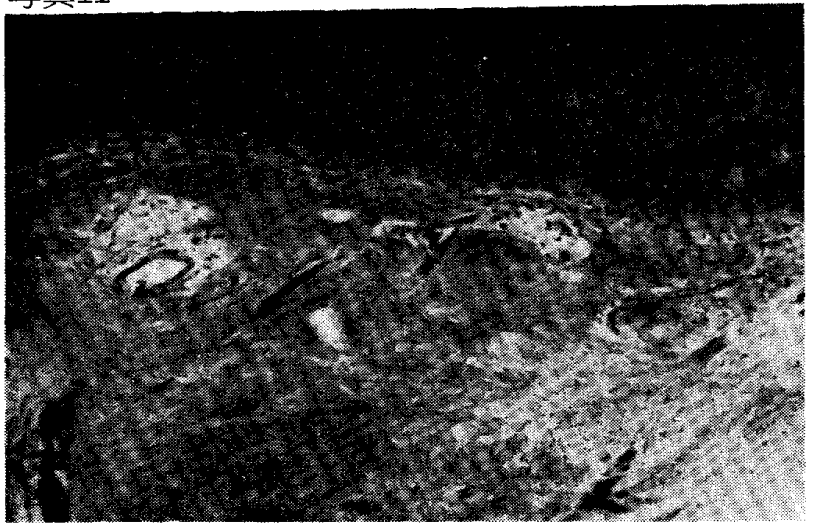

写真12

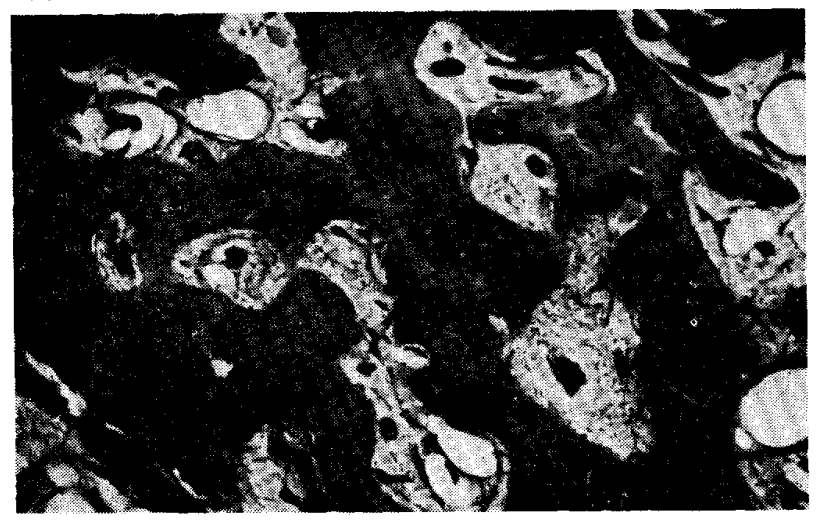

写真13

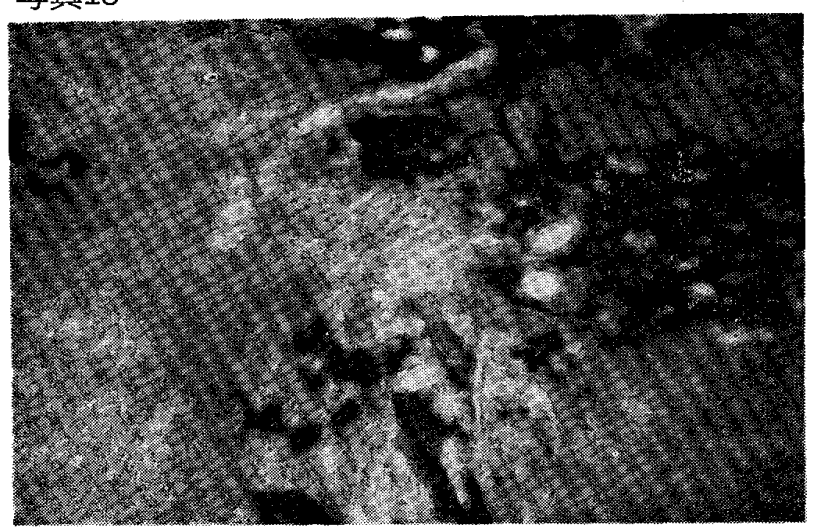

: 写真14

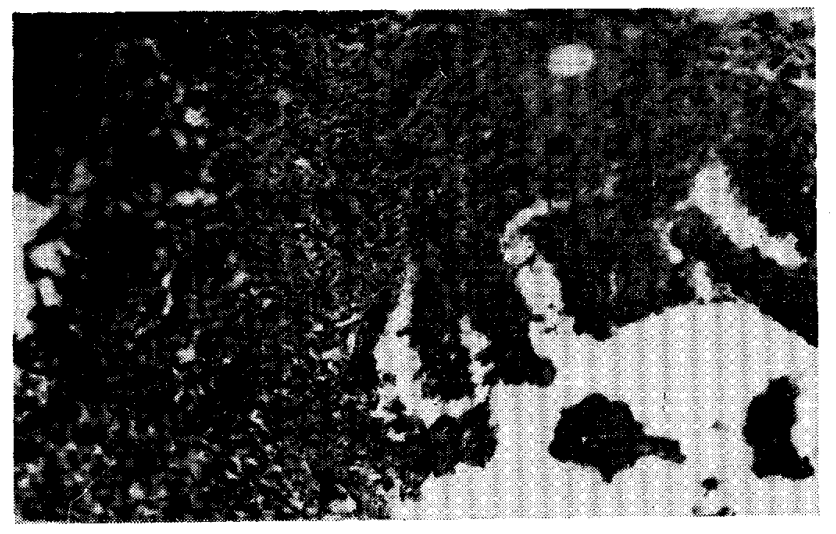

写真15

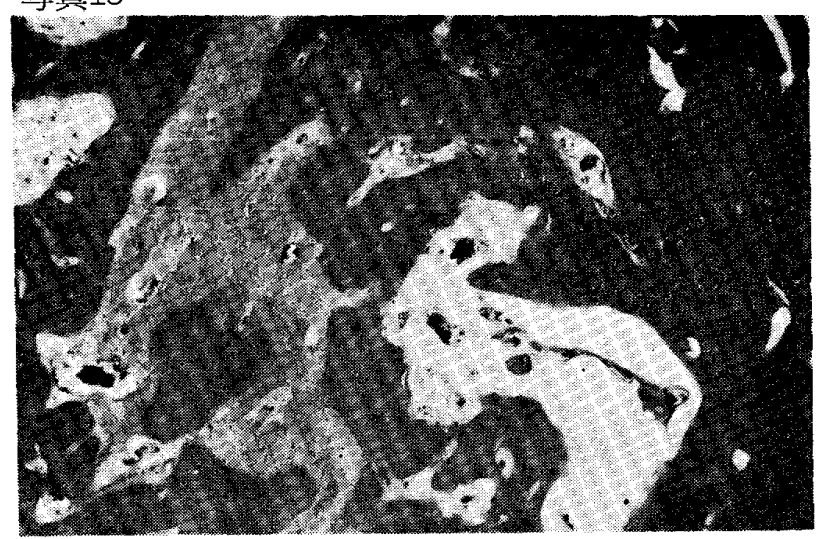

写真16

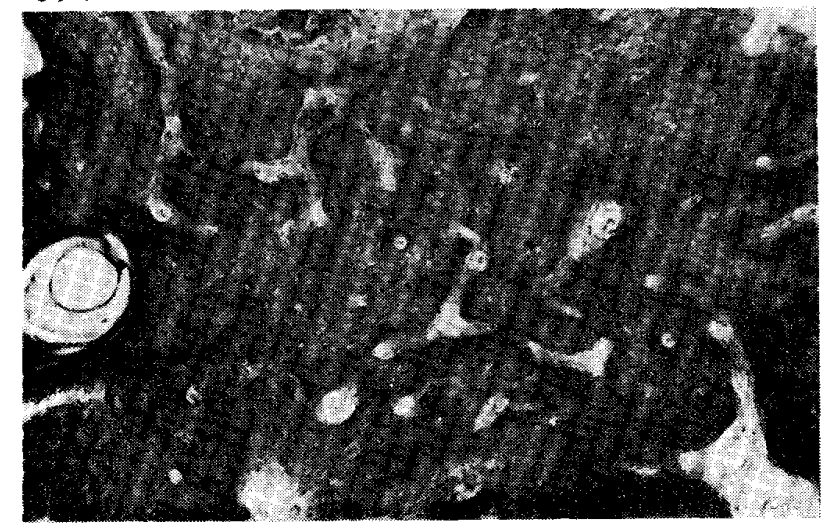




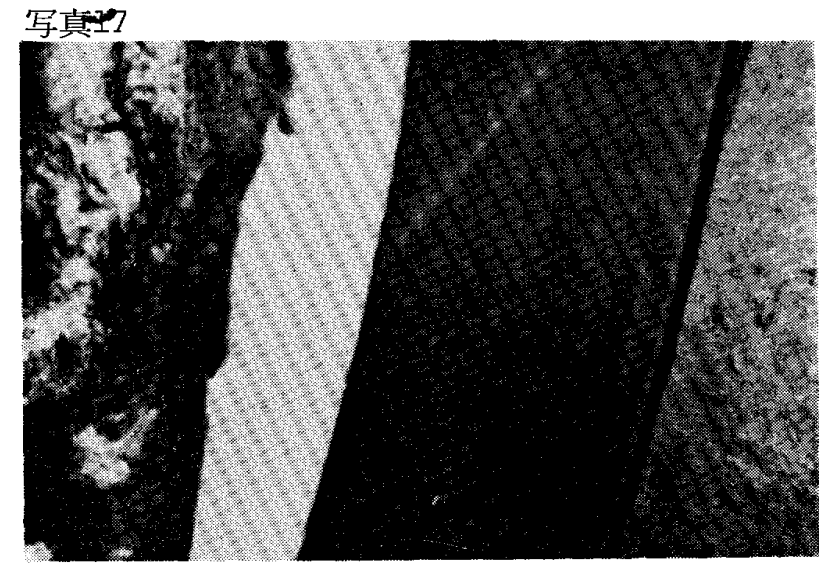

写真18

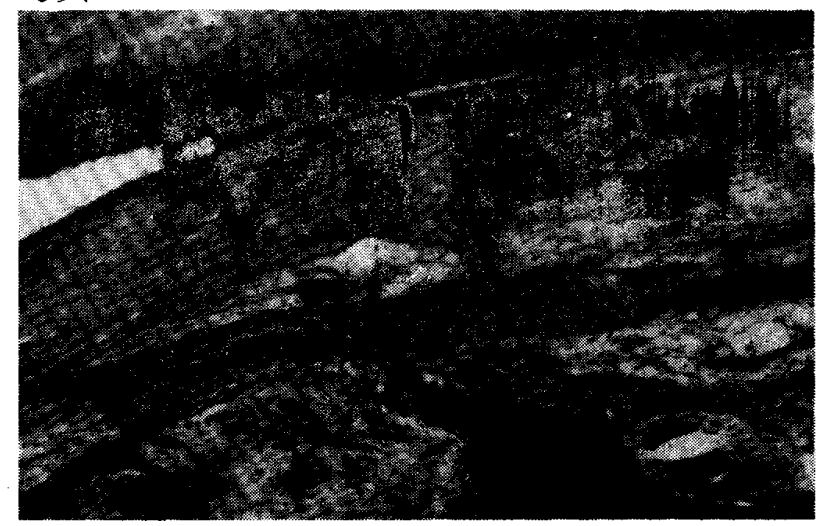

写真19

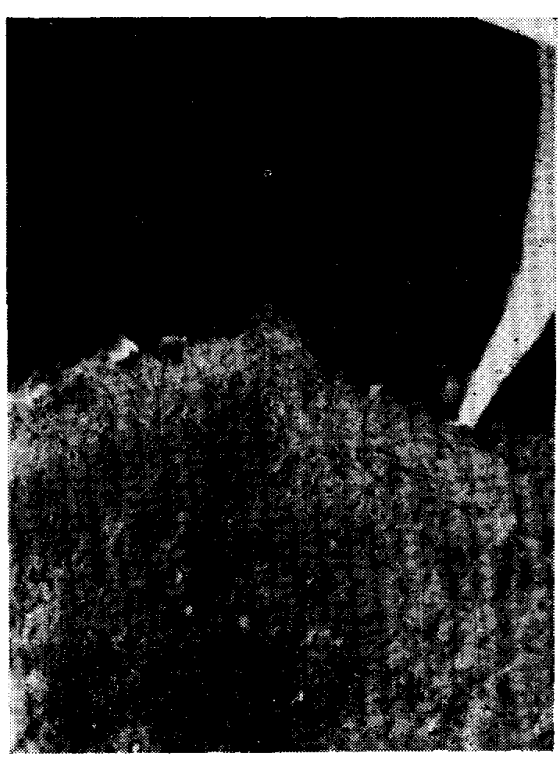

